\title{
SECONDARY PREVENTION OF ACUTE CORONARY SYNDROME. SOCIO-ECONOMIC AND LIFESTYLE DETERMINANTS: A LITERATURE REVIEW
}

\author{
Venetia Notara1, Demosthenes B. Panagiotakos ${ }^{1}$, Christos E. Pitsavos ${ }^{2}$ \\ 'Department of Nutrition and Dietetics, School of Health Science and Education, Harokopio University, Athens, Greece \\ ${ }^{2}$ First Cardiology Clinic, School of Medicine, University of Athens, Athens, Greece
}

\begin{abstract}
SUMMARY
Although cardiovascular disease mortality rates seem to decline, especially among middle-aged people in developed countries, the prevalence of acute coronary syndrome (ACS) increases, representing the most common cause of morbidity in both developed and developing countries and generating large economic burden. It is estimated that one fifth of the ACS patients die suddenly and half of them belong to a fast growing population age-group, i.e., those between 70 and 80 years. A substantial number of these deaths has been attributed to various lifestyles, modifiable factors; therefore, it can be prevented. However, factors such as dietary habits and behaviours, physical activity, life stress and smoking habits, although thoroughly discussed, are not well understood and appreciated in the spectrum of secondary ACS prevention. The latter deserves further attention under the prism of socio-economic status that has changed dramatically in the last years in some populations. The aim of this review was to discuss the role of lifestyle factors on secondary ACS prevention under the prism of individual's socio-economic status. Based on the retrieved information it was revealed that there is vast evidence that secondary prevention of cardiovascular events cannot be accomplished simply through medical treatment, but it requires a multifaceted approach incorporating lifestyle modifications, too. Therefore, public health policy endeavours should be directed towards multifocal strategies, i.e., to motivate and support cardiac patients to consistently follow treatment regimens and to establish more effective and efficient community lifestyle interventions.
\end{abstract}

Key words: acute coronary syndrome, nutritional habits, physical activity, smoking status, alcohol consumption, lifestyle modifications, socioeconomic status

Address for correspondence: D. B. Panagiotakos, 46 Paleon Polemiston St., 16674, Glyfada, Greece. E-mail: d.b.panagiotakos@usa.net

\section{INTRODUCTION}

According to recent cardiovascular disease (CVD) statistics, although death rates seem to decline or be constant, especially among middle-aged people, the prevalence of acute coronary syndrome (ACS) increases, representing the most common cause of morbidity in both developed and developing countries (1). The latter has also serious economic consequences generating large burden in almost all societies, especially under the current global financial crisis (2). Moreover, a vast majority of ACS patients will have a recurrent event and a substantial number of these events are attributed to various lifestyle modifiable factors such as dietary habits and behaviours, physical activity, life and occupational stress, and smoking habits (3). Although these factors have long been studied and discussed, it seems that they are not well understood and appreciated in the spectrum of secondary ACS prevention. The aforementioned considerations deserve further attention, especially now, when significant socio-economic changes occur in societies. Thus, the aim of this review was to present current scientific knowledge on the relationship between lifestyle behavioural factors and secondary ACS prevention, and to discuss how these may be modified by individuals' socio-economic status, especially under the prism of the current financial crisis.

\section{Literature Search}

A literature review of national and international studies was performed in databases of PubMed, Scopus and Scholar Google using key words and terms such as acute coronary syndrome; coronary heart disease; unstable angina; incidence future trends and burden of CVD; health care expenditures of CVD; secondary prevention of ACS (including secondary prevention goals, predictors); lifestyle-behavioural factors and secondary prevention of CVD (i.e., nutritional habits, physical activity, smoking status, alcohol consumption); socio-economic status and CVD (including educational level, occupation). A ten-year time frame was set (2003-2013) in order to include the most recent and updated prospective cohorts, case-control, cross-sectional studies, randomised clinical trials as well as meta-analysis with some exceptions for including large-scale studies or reports with critical data and definitions. Retrieved studies were published in English language. Studies referring only to medical treatment and clinical therapeutic interventions such as coronary angioplasty or coronary artery bypass were excluded since this was beyond the aim of this review. Furthermore, public health policy statements by national organizations and related papers were also retrieved and discussed. Thus, 203 original research papers were retrieved, published between May 2003 and June 2013; 63 of them were discussing prospective cohorts, 8 case-control studies, 53 cross- 
sectional studies, 29 randomised clinical trials, and 50 were discussing meta-analysis and systematic reviews.

\section{Lifestyle Factors and Secondary Prevention of ACS}

The British Heart Foundation stated that ACS is the most preventable manifestation of CVD and secondary prevention should be focused on the adoption of healthier lifestyle behaviours. Additionally, more than $50 \%$ in the reduction of ACS mortality is attributable to favourable changes in risk factors, while $43 \%$ to new medical and surgical treatment (4). In cases when health-risk behaviours are combined with hypertension, obesity, hypercholesterolemia, and type 2 diabetes mellitus, they account for over three quarters of ischaemic heart disease and they lead to a life span drop by almost 5 years (5). Furthermore, the American Heart Association and the American College of Cardiology have strongly recommended that healthier lifestyle patterns can be regarded as a "risk-reduction therapy" for secondary prevention of CVD (6). Despite the well-known benefits of making healthier choices, it should be acknowledged that patients do not follow the recommended advices, even shortly after an ACS event and accordingly adherence to healthy habits has declined in the last years, posing an alarming increase in the future trends of CVD (7).

\section{Mediterranean Diet and Secondary ACS Prevention}

Mediterranean diet has long been evaluated in relation to CVD prevention. Since the 1970s, where the historical Seven Countries Study, under the guidance of Ancel Keys, first reported the beneficial health effects of the traditional Mediterranean diet on CVD mortality in seven countries and 16 cohorts around the world (8), there has been developed a strong body of scientific evidence associating Mediterranean diet with better human health, and particularly with reduced CVD morbidity and mortality risk, through several mechanisms (9). However, the influence of this traditional dietary model on secondary prevention of CVD has not been understood and appreciated. The Lyon Diet Heart Study was one of the first studies that evaluated the role of Mediterranean type of diet on secondary prevention of CVD in free living subjects (10). The main goal was to measure the effectiveness of a certain dietary pattern, increased intake of fruits, vegetables, cereals, fish and $\alpha$-linolenic acid. Indeed, the findings were impressive demonstrating a $50 \%$ to $70 \%$ lower risk of recurrent heart disease events among subjects who followed the intervention dietary pattern. In line with the Lyon Heart Study, the GREECS observational study in the short-term and up to 1-year follow-up revealed that ACS patients who followed a dietary pattern close to the Mediterranean experienced lower risk of recurrent cardiac events (11). Within the framework of the European Perspective In Cancer (EPIC) project, the investigators, pointed out that the association between Mediterranean diet and mortality was about 5 times stronger among coronary patients as compared to healthy individuals (12).

Regarding other dietary factors, increased salt consumption has been reported to have an adverse effect on the disease prognosis (13), however, it was observed that the effect of salt intake was not associated with the development of ACS as long as the participants followed a balanced diet (14). Fish intake also seemed to have a protective effect on the disease progression; particularly mortality from CHD may be reduced by eating fish at least once a week (15). Regarding the consumption of dietary fats, polyunsaturated and monounsaturated fats have been associated with a substantially reduced mortality risk, while trans-fatty acids, saturated fat and cholesterol intake should be avoided (16). However, it is worth mentioning that clinical benefits of the most abundant polyunsaturated fatty acids, omega- 6 linoleic acid have not yet been established (17). Finally, the inverse association between red meat intake and risk of CHD has not been adequately supported (18).

Despite the favourable association between healthy diet and reduced CVD risk, maintaining dietary changes in daily life after an ACS event seems extremely difficult. The dynamics of dietary factors and CHD progression are complex and multi-factorial. Thus, to enhance adherence to dietary recommendations in the long run, further efforts are needed to define public health strategies for continuous motivation. According to the most recent Joint ESC Guidelines, the future challenge is to translate nutritional guidelines into diets that are attractive to people and to find ways to make people change their long-standing dietary habits (19) (Table 1).

\section{Alcohol Consumption and Secondary ACS Prevention}

Alcohol drinking has also received a special attention in CVD prevention. In the early 1980s, the Framingham Heart Study documented the cardioprotective effect of light to moderate alcohol consumption (up to two drinks/day) in primary CVD prevention (20). Since then, recent data have shown a relationship between moderate drinking and reduced mortality in CVD patients (21). Regarding the type of alcoholic beverages and the pattern of drinking, it has been demonstrated that moderate consumption of wine during meals could reduce mortality, while wine drinking outside meals increased mortality rates (22).

The Lyon Diet Heart Study showed that moderate wine consumption in CHD patients was associated with higher levels of "marine" $\omega 3$ fatty acids in plasma (23). It seemed that alcohol had an "aspirin-like" thrombolytic effect by reducing bloodclotting risk (24). However, some studies support that the beneficial effects of moderate drinking after a heart disease should be evaluated with caution and must be tailored-made since they may be modulated by genetic factors, by the pre-MI frequency of alcohol-consumption and by other dietary, lifestyle and socioeconomic factors that influence the underlying risk of coronary heart disease $(25,26)$.

At this point it should be acknowledged that there is a strong correlation between drinking and cigarette smoking, probably due to the fact that prolonged use of both substances may create dependency (27). Another critical aspect on the health benefits of moderate alcohol consumption is that people who drink in moderation may have a different lifestyle habits from people who do not drink or drink heavily, and the obvious healthy effects may be mostly due to favourable risk profiles in moderate drinkers (28). However, further research is needed to reveal the causal effect between moderate alcohol consumption and disease progression (Table 2).

\section{Physical Activity Status and Secondary ACS Prevention}

Physical activity is an important health-related determinant. Exercise seemed to have beneficial effects on CVD risk by 
Table 1. Review of studies that have evaluated the role of Mediterranean Diet in secondary prevention of ACS

\begin{tabular}{|c|c|c|c|c|}
\hline Source & Study target population & Type of study & Follow-up period/Study design & Main findings \\
\hline Erkkila et al. 2003 (16) & $\begin{array}{l}\text { A total of } 1,302 \text { Greek } \\
\text { CHD patients ( } 726 \text { men, } \\
576 \text { women) }\end{array}$ & Cohort study & $\begin{array}{l}5 \text { years follow-up of patients } \\
\text { participating in the EUROASPIRE } \\
\text { study recording dietary intakes } \\
\text { through food records and serum } \\
\text { lipids. }\end{array}$ & $\begin{array}{l}\text { High proportions of } n-3 \text { fatty acids } \\
\text { in serum lipids were associated } \\
\text { with a substantially reduced risk } \\
\text { of death. }\end{array}$ \\
\hline $\begin{array}{l}\text { Panagiotakos et al. } 2006 \\
\text { (11) }\end{array}$ & $\begin{array}{l}\text { A total of } 2,172 \text { ACS } \\
\text { patients }(1,649 \text { men, } 523 \\
\text { women) from } 6 \text { hospitals }\end{array}$ & Cohort study & $\begin{array}{l}1 \text { year of follow-up, the patients } \\
\text { were surveyed for nutritional } \\
\text { and lifestyle habits, socio-demo- } \\
\text { graphic characteristics. Medical } \\
\text { information was retrieved through } \\
\text { patients' hospital records. }\end{array}$ & $\begin{array}{l}\text { Background dietary habits close } \\
\text { to the Mediterranean diet seemed } \\
\text { to be associated with lower sever- } \\
\text { ity of coronary heart disease. }\end{array}$ \\
\hline $\begin{array}{l}\text { Trichopoulou et al. } 2007 \\
\text { (12) }\end{array}$ & $\begin{array}{l}\text { A total of } 2,671 \mathrm{Ml} \text { pa- } \\
\text { tients from } 9 \text { countries }\end{array}$ & $\begin{array}{l}\text { Population-based } \\
\text { prospective investigation }\end{array}$ & $\begin{array}{l}6.7 \text { years of follow-up (the } \\
\text { EPIC cohort), recording dietary } \\
\text { intakes through a validated food } \\
\text { frequency questionnaire. }\end{array}$ & $\begin{array}{l}\text { The Mediterranean diet pattern } \\
\text { was associated with substantial } \\
\text { reduction of total mortality of coro- } \\
\text { nary patients in the community. }\end{array}$ \\
\hline He et al. 2004 (15) & $\begin{array}{l}\text { A total of } 222,364 \text { indi- } \\
\text { viduals with an average } \\
11.8 \text { years of follow-up }\end{array}$ & $\begin{array}{l}\text { Meta-analysis of } \\
\text { prospective cohort studies }\end{array}$ & $\begin{array}{l}\text { Observational studies from } 1966 \\
\text { to } 2003 \text {, studying the association } \\
\text { between fish intake and CHD } \\
\text { mortality. }\end{array}$ & $\begin{array}{l}\text { Fish consumption was inversely } \\
\text { associated with fatal } \mathrm{CHD} \text {. }\end{array}$ \\
\hline $\begin{array}{l}\text { De Lorgeril et al. } 1999 \\
\text { (10) }\end{array}$ & $\begin{array}{l}\text { A total of } 275 \text { ACS } \\
\text { patients }\end{array}$ & $\begin{array}{l}\text { Randomized secondary } \\
\text { prevention trial }\end{array}$ & 4 years of follow-up & $\begin{array}{l}\text { The protective effect of the } \\
\text { Mediterranean dietary pattern was } \\
\text { maintained up to } 4 \text { years after the } \\
\text { first infarction. }\end{array}$ \\
\hline
\end{tabular}

Table 2. Review of studies that have evaluated the role of Alcohol Consumption in secondary prevention of ACS

\begin{tabular}{|l|l|l|l|l|}
\hline Source & Study target population & Type of study & Follow-up period/Study design & Main findings \\
\hline Rehm et al. 2003 (22) & - & Literature review & - & $\begin{array}{l}\text { Heavy drinking occasions as well } \\
\text { as drinking outside meals were } \\
\text { related to increased CHD risk. } \\
\text { Physiological mechanisms have } \\
\text { been identified to explain this } \\
\text { complex relationship between } \\
\text { alcohol and CHD. }\end{array}$ \\
\hline Mukamal et al. 2001 (26) & $\begin{array}{l}\text { A total of 1,913 adults } \\
\text { hospitalized with myocar- } \\
\text { dial infarction }\end{array}$ & $\begin{array}{l}\text { Prospective - cohort } \\
\text { study }\end{array}$ & 4 years of follow-up & $\begin{array}{l}\text { Moderate alcohol consumption } \\
\text { in the year prior to AMI was } \\
\text { associated with reduced mortality } \\
\text { following infarction. }\end{array}$ \\
\hline Collins et al. 2009 (24) & - & Review article & - & $\begin{array}{l}\text { Alcohol had an "aspirin-like" } \\
\text { thrombolytic effect by reducing } \\
\text { blood-clotting risk. }\end{array}$ \\
\hline Lee et al. 2009 (28) & $\begin{array}{l}\text { A total of 12,519 subjects } \\
\text { Study }\end{array}$ & $\begin{array}{l}\text { Prospective - cohort } \\
\text { study }\end{array}$ & Data collection through interviews & $\begin{array}{l}\text { Moderate drinkers had better risk } \\
\text { factor profiles than non-drinkers, } \\
\text { including higher SES. }\end{array}$ \\
\hline Costanzo et al. 2010 (21) & $\begin{array}{l}\text { A total of 16,351 CVD } \\
\text { patients }\end{array}$ & Meta-analysis study & $\begin{array}{l}\text { 54 publications were retrieved, } \\
\text { including only patients with } \\
\text { diagnosed coronary heart disease }\end{array}$ & $\begin{array}{l}\text { In CVD patients, light to moder- } \\
\text { ate alcohol consumption was } \\
\text { significantly associated with a } \\
\text { lower incidence of cardiovascular } \\
\text { and all-cause mortality. }\end{array}$ \\
\hline
\end{tabular}

modifying the metabolic, haemostatic, hormonal, and vascular endothelial function (29).

It has been suggested that the key point between physical inactivity and CVD was obesity, through which several pathological mechanisms lead to atherosclerotic process (30). A daily or most days of the week, 30 minute moderate physical activity, could contribute to serious improvements in cardiovascular health (29). Marital status has been also stated that positively influence physical activity and participation in cardiac rehabilitation programmes $(31,32)$.

Physical activity has been regarded as the most important non-pharmaceutical mean for secondary CVD prevention but the type, frequency and intensity of activity must be based on a comprehensive medical judgement and tailored to the patient's clinical profile (co-morbidities, disability status, preferences, 
Table 3. Review of studies that have evaluated the role of Physical Activity in secondary prevention of ACS

\begin{tabular}{|c|c|c|c|c|}
\hline Source & Study target population & Type of study & Follow-up period/Study design & Main findings \\
\hline Pitsavos et al. 2008 (29) & $\begin{array}{l}2,172 \text { ACS patients ( } 76 \% \\
\text { men and } 24 \% \text { women) }\end{array}$ & Cohort study & $\begin{array}{l}\text { Patients who were hospitalized in } \\
\text { the cardiology clinics or the emer- } \\
\text { gency units of } 6 \text { major general hos- } \\
\text { pitals in Greece from 2003-2004. To } \\
\text { evaluate the assoc. between PA \& } \\
\text { clinical outcome. }\end{array}$ & $\begin{array}{l}\text { Physical activity was associ- } \\
\text { ated with a reduced severity } \\
\text { of ACS, reduced in-hospital } \\
\text { mortality rates, and improved } \\
\text { short-term prognosis. }\end{array}$ \\
\hline Logue et al. 2011 (30) & $\begin{array}{l}1,300 \text { men (mean age } 55 \\
\text { years) with hypercholes- } \\
\text { terolemia with no history } \\
\text { of CVD }\end{array}$ & $\begin{array}{l}\text { Prospective observa- } \\
\text { tional study }\end{array}$ & $\begin{array}{l}\text { Subjects' BMI was evaluated in rela- } \\
\text { tion to fatal or non-fatal CHD events. }\end{array}$ & $\begin{array}{l}\text { The key point between physical } \\
\text { inactivity and CVD was obesity, } \\
\text { through which several patho- } \\
\text { logical mechanisms lead to } \\
\text { atherosclerotic process. }\end{array}$ \\
\hline Green et al. 2013 (31) & 107 ACS patients & $\begin{array}{l}\text { Prospective observa- } \\
\text { tional study }\end{array}$ & $\begin{array}{l}\text { Partner status and physical activity. } \\
\text { Accelerometers were used to meas- } \\
\text { ure physical activity after hospital } \\
\text { discharge. }\end{array}$ & $\begin{array}{l}\text { Living alone was associated } \\
\text { with adverse outcomes after } \\
\text { acute coronary syndromes. }\end{array}$ \\
\hline Vanhees et al. 2012 (33) & - & Review article & - & $\begin{array}{l}\text { Physical activity has been } \\
\text { regarded as the most important } \\
\text { non-pharmaceutical mean for } \\
\text { secondary CVD prevention, } \\
\text { but need to be tailored to the } \\
\text { patients' needs. }\end{array}$ \\
\hline
\end{tabular}

etc.) (33). According to the latest version of the ESC Guidelines there is a gap in the evidence establishing the duration/intensity of physical activity among high-risk groups (i.e., elderly, patients with advanced chronic heart failure), the dose-response relationship between cardiorespiratory fitness and reduction in CVD risk and the long-term prognostic gain in patients with chronic heart failure (19). Issues regarding population-based approaches, tailored lifestyle interventions, assessment of programmes' duration, cost and resources need further investigation so as to attain improved outcomes (Table 3).

\section{Smoking Status and Secondary ACS Prevention}

The link between smoking and heart disease has been documented since the 1960s in the Framingham Heart and the Seven Countries studies $(8,34)$. Up to date continuous data reinforce the association between smoking and excess CVD morbidity and mortality (35). The British Heart Foundation reported that CVD patients who quit smoking reduce their CVD death rate by about $40 \%$ - substantially more than the reductions seen with statins $(22 \%)$ or aspirin $(15 \%)(4)$. The possible explanation is that smoking accelerated atherosclerosis (i.e. damage to the endothelial lining) process by increasing LDL and reducing HDL cholesterol blood levels, raising blood pressure, increasing tendency for blood clotting by impeding endogenous fibrinolysis and damaging cells that line coronary arteries (36).

However, despite the vast evidence of the harmful cardiovascular effects of cigarette smoking, patients fail to follow physicians' recommendations to quit smoking, and even if they stop during their hospitalisation, they relapse immediately after discharge (37). Almost $21 \%$ of the cohort-patients who were followed in the EUROASPIRE II, conducted three and half years after the EUROASPIRE I, were current smokers (38). More than half of CHD patients did not quit smoking even 1 month after hospital discharge because of an unfavourable smoking and disease his- tory and a poor social cognitive profile (39). Human behaviour plays a critical role in the primary and secondary disease prevention. Cognitive-behavioural methods intend to explain and predict healthy behaviours and thus can ultimately contribute to implementation of more effective health promotion strategies and consequently to the improvement of public health.

Even though intervention programmes seem to have a sustained beneficial short-term effect in hospitalized patients, their effect is hard to remain if patients are not followed-up for longer period since they revert to previous lifestyle habits. The European Society of Cardiology in the Committee for Practice Guidelines (CPG) reported that smoking cessation is difficult to achieve in the longterm and a simple physician's advice is not sufficient to persuade a coronary patient to give up smoking. Thus, more active counselling, systematic follow-up and interventions are necessary (40). The Joint ESC Guidelines proposed that public health measures, like smoking bans in public areas, tobacco taxation and media campaigns are efficient aids in preventing smoking uptake and supporting smoking cessation (19). Consequently, behavioural interventions, routine screening programmes and supportive environment at home or workplace will substantially improve the identification, treatment and outcomes in CVD patients who use tobacco (Table 4).

\section{Socio-economic Status and Secondary Prevention of ACS Event}

Socio-economic status (SES) is a combined measure incorporating economic (income), social (education) and work (occupation) status. The WHO Commission on Social Determinants of Health indicated that over $80 \%$ of CVD deaths occur in low and middle income countries as a consequence of unequal living conditions, mal-distribution of health care and poor social policies (41). It has been estimated that low-income people do not have sufficient opportunities to buy healthy, affordable food leading to an increase of diet-related diseases like obesity, diabetes and CHD (42). The 
Table 4. Review of studies that have evaluated the role of Smoking Status in secondary prevention of ACS

\begin{tabular}{|l|l|l|l|l|}
\hline Source & Study target population & Type of study & Follow-up period/Study design & Main findings \\
\hline $\begin{array}{l}\text { De Bacquer et al. } 2012 \\
\text { (35) }\end{array}$ & $\begin{array}{l}\text { CHD patients aged } \leq 70 \\
\text { years from 12 European } \\
\text { countries }\end{array}$ & Cohort study & $\begin{array}{l}28,143 \text { persons - years of } \\
\text { follow-up }\end{array}$ & $\begin{array}{l}\text { The study underlined the impor- } \\
\text { tance of smoking cessation in } \\
\text { secondary prevention. }\end{array}$ \\
\hline Newby et al. 1999 (36) & $\begin{array}{l}12 \text { smokers and 12 } \\
\text { non-smokers, free from } \\
\text { vascular disease }\end{array}$ & Clinical trial study & $\begin{array}{l}\text { Subjects received unilateral bra- } \\
\text { chial artery infusions of substance } \\
\text { P (Clinalfa AG). }\end{array}$ & $\begin{array}{l}\text { Smoking accelerated athero- } \\
\text { thrombosis through a reduction in } \\
\text { the acute fibrinolytic capacity. }\end{array}$ \\
\hline Pyrgakis 2009 (37) & - & Review article & - & $\begin{array}{l}\text { Patients failed to follow recom- } \\
\text { mendations to quit smoking, and } \\
\text { even if they stopped during their } \\
\text { hospitalisation, they relapsed im- } \\
\text { mediately after discharge. }\end{array}$ \\
\hline Scholte et al. 2006 (38) & $\begin{array}{l}\text { A total of 5,551 CHD } \\
\text { patients }\end{array}$ & Cohort study & $\begin{array}{l}\text { EUROASPIRE II, which was } \\
\text { undertaken in 15 European } \\
\text { countries during 1999-2000. }\end{array}$ & $\begin{array}{l}\text { The prevalence of smoking in } \\
\text { European CHD patients remained } \\
\text { high with one out of each five pa- } \\
\text { tient's smokes, despite a personal } \\
\text { advice to stop. }\end{array}$ \\
\hline Berndt 2012 (39) & $\begin{array}{l}\text { A total of 133 cardiac } \\
\text { patients }\end{array}$ & Cohort study & $\begin{array}{l}\text { Patients completed questionnaires } \\
\text { at hospital admission and 1 month } \\
\text { after discharge. }\end{array}$ & $\begin{array}{l}\text { One third of cardiac patients were } \\
\text { at high risk of continuing smoking } \\
\text { after hospital discharge because } \\
\text { of an unfavourable smoking and } \\
\text { disease history and a poor social } \\
\text { cognitive profile. }\end{array}$ \\
\hline
\end{tabular}

aforementioned issues deserve further attention, especially under the prism of the recent financial crisis that has affected healthcare system. Slow economic growth rate, population ageing, skewed manpower, low level of public expenditure, inadequate hospitals and low level of primary care will place increasing pressure on healthcare resources. There is a widespread agreement that in stressful economic and social circumstances the demand on public health services is increased for the reason that patients turn from the private to public sector services since the cost of care is lower (43).

Nevertheless, longitudinal studies addressing the association between SES and re-currency of ACS among CVD patients are very limited and poorly understood.

It has been revealed that survivors living in a deprived neighbourhood were at higher risk of repeated hospital admissions (44). Moreover, if low income is accompanied by low educational level, then the mortality risk after an ACS is doubled. Probably the least

Table 5. Review of studies that have evaluated the role of Socio-economic Status (SES) in secondary prevention of ACS

\begin{tabular}{|c|c|c|c|c|}
\hline Source & Study target population & Type of study & Follow-up period/Study design & Main findings \\
\hline $\begin{array}{l}\text { Pitsavos et al. } 2002 \\
(45)\end{array}$ & $\begin{array}{l}750 \text { ACS patients and } \\
869 \text { controls with no CVD }\end{array}$ & Case-control & $\begin{array}{l}\text { Trends in cardiovascular risk fac- } \\
\text { tors were examined among cases } \\
\text { and controls, regarding education- } \\
\text { al level by years of schooling. }\end{array}$ & $\begin{array}{l}\text { In all subjects education status } \\
\text { was related to economic and } \\
\text { occupation status, smoking } \\
\text { habits, physical inactivity, alcohol } \\
\text { consumption and non-compliance } \\
\text { to treatment. The least-educated } \\
\text { subjects adopted a more adverse } \\
\text { lifestyle than the more-educated } \\
\text { subjects. }\end{array}$ \\
\hline $\begin{array}{l}\text { Panagiotakos et al. } 2008 \\
(46)\end{array}$ & 2,172 ACS patients & $\begin{array}{l}\text { Prospective - cohort } \\
\text { study }\end{array}$ & 1 year of follow-up & $\begin{array}{l}\text { Unmarried ACS patients were at } \\
\text { higher risk of fatal events com- } \\
\text { pared to married patients. }\end{array}$ \\
\hline $\begin{array}{l}\text { Lammintausta et al. } 2013 \\
\text { (47) }\end{array}$ & 15,330 ACS patients & Prospective study & 9 years of follow-up & $\begin{array}{l}\text { Single living increased the risk of } \\
\text { having a heart attack and worsens } \\
\text { its prognosis. }\end{array}$ \\
\hline Koren et al. 2012 (44) & $\begin{array}{l}\text { A total of } 1,1164 \text { acute } \mathrm{Ml} \\
\text { patients } \leq 65 \text { years }\end{array}$ & Cohort study & 13 years of follow-up & $\begin{array}{l}\text { Ml survivors living in a deprived } \\
\text { neighbourhood were at higher risk } \\
\text { of repeated hospital admissions } \\
\text { because of ACS. }\end{array}$ \\
\hline $\begin{array}{l}\text { Aboa-Eboulé et al. } 2007 \\
\text { (49) }\end{array}$ & $\begin{array}{l}\text { A total of } 972 \text { patients } \\
\text { with first myocardial } \\
\text { infarction }\end{array}$ & $\begin{array}{l}\text { Prospective - cohort } \\
\text { study }\end{array}$ & 9 years of follow-up & $\begin{array}{l}\text { Chronic job strain after a first Ml } \\
\text { was associated with an increased } \\
\text { risk of recurrent } \mathrm{CHD} \text {. }\end{array}$ \\
\hline
\end{tabular}


educated patients adopt less healthy lifestyle habits compared to the more educated, as supported by the CARDIO2000 study in which the coronary risk increased by $82 \%$ for individuals with a lower level of education, and by $65 \%$ for individuals with an average education compared to those with an academic education (45). In general, educational level seems to play an important role in the mortality and life expectancy rates.

Another interesting element examined in the GREECS study, was the influence of marital status in the short-term prognosis of patients with ACS. Never-married had 2.7-times higher risk of dying during the first 30-days following hospitalization compared to married ones (46). This result, in accordance with the populationbased study recording 15,330 cases of ACS aged 35-99 years in Finland in 1993-2002, shows that unmarried patients had a worsen prognosis both in men and women regardless of age (47). Certainly, the data providing a relationship between marital status and prognosis of a second ACS event is not very clear since family situation is rather more complicated issue which can enhance or weaken well-being since several dynamics are involved in human relationships. Nevertheless, future research should be focused on the psychosocial support of certain high-risk patients with established CHD. Cardiac patients often develop depressive and anxiety episodes which not only complicate the course of the disease but also remain under-diagnosed and under-treaded. Therefore, both societies and health care professionals should be able to identify, support and monitor patients susceptible to mental health problems (48).

Finally, very little is known about the relationship among occupational stress strongly related to SES and the risk of post-ACS event. Chronic job strain after a first ACS was associated with an increased risk of recurrent CHD (49). Psychological stress may also influence the risk of CHD more indirectly via healthdamaging behaviours such as smoking, physical inactivity or heavy alcohol consumption (Table 5).

\section{CONCLUSIONS}

Cardiovascular diseases are the dominant contributors to the global economic burden of non-communicable diseases. Therefore, secondary prevention relies on early detection of disease process and application of interventions to prevent disease progression. The AHA/ACCF Secondary Prevention and Risk Reduction Therapy for Patients with Coronary and Other Atherosclerotic Vascular Disease: 2011 Update indicated the following prevention goals and management: smoking cessation, blood pressure control, healthy diet, lipid management, physical activity, weight management, diabetes management, antiplatelet agents and anticoagulants, renin, angiotensin and aldosterone system blockers, beta-blockers, and influenza vaccination (6). In this point, it is worth mentioning that the above goals should be achieved even in the framework of primary prevention, so as to protect healthy people from developing the disease. Smoking cessation, moderate physical activity (at least 30 minutes 5 times per week), healthy eating habits, no overweight, blood pressure below 140/90 $\mathrm{mmHg}$, blood cholesterol below $5 \mathrm{mmol} / \mathrm{L}$ (190 $\mathrm{mg} / \mathrm{dl}$ ), normal glucose metabolism and avoidance of excessive stress are the characteristics associated with cardiovascular health as stated in Article 3 of the European Heart Health Charter (50).

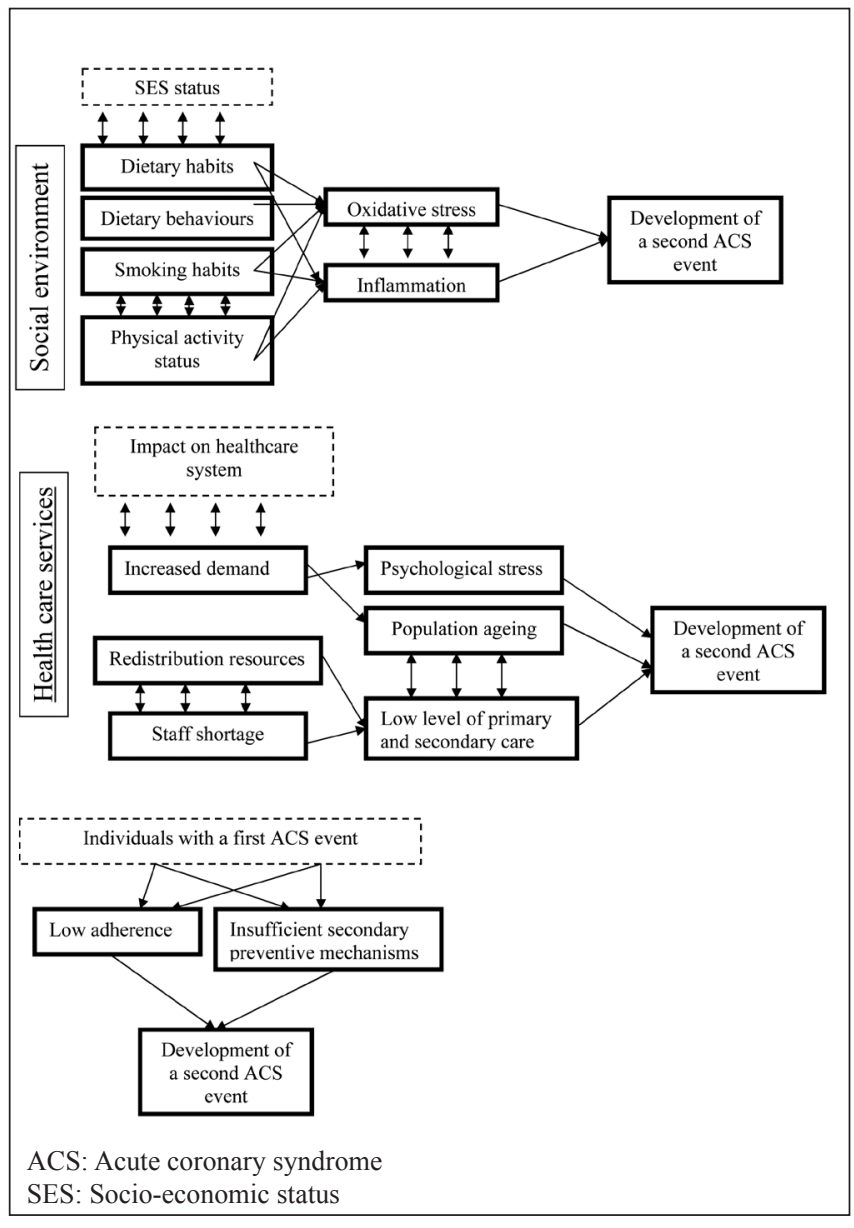

Fig. 1. A conceptual framework regarding the role of modifiable lifestyle behaviours and the development of a second ACS event.

The cardiac patient is confronted with a great challenge in adjusting to new lifestyle pattern in a way that he/she was not used to for many years. It has been aforementioned that modest reductions in major risk factors such as smoking, cholesterol and blood pressure levels might have gained four times as many life-years as did cardiology treatments. Nevertheless, it is well documented that, even after a short period of a post-ACS, patients report a poor adherence to medical recommendations and lifestyle modifications. The economic costs of poor adherence and the impact on health-related quality of life highlight the pressing need for quick and successful multi-focal actions, including medical treatment, dietary guidance, lifestyle counselling, stress mitigation techniques, and social support (Fig. 1).

The studies presented in this review were mainly examining the relationship between secondary ACS prevention through lifestyle habits. Positive lifestyle motivations, cognitive-behavioural therapy and supportive social and family environment may favourably affect the adverse disease prognosis.

\section{Conflict of Interests}

None declared 


\section{REFERENCES}

1. World Health Organization. Media centre. Cardiovascular diseases (CVDs). Fact sheet no. 317 [Internet]. Geneva: WHO; 2013 [cited 2014 Aug 23] Available from: http://www.who.int/mediacentre/factsheets/fs317/en/.

2. Roggeri DP, Roggeri A, Rossi E, Cinconze E, De Rosa M, Maggioni AP; ARNO Cardiovascular Observatory. Direct healthcare costs and resource consumption after acute coronary syndrome: a real-life analysis of an Italian subpopulation. Eur J Prev Cardiol. 2014 Sep;21(9):1090-6.

3. Vestfold Heartcare Study Group. Influence on lifestyle measures and fiveyear coronary risk by a comprehensive lifestyle intervention programme in patients with coronary heart disease. Eur J Cardiovasc Prev Rehabil. 2003 Dec;10(6):429-37.

4. Capewell S, Allender S, Critchley J, LLoyd-Williams F, O'Flaherty M, Rayner M, et al. Modelling the UK burden of cardiovascular disease to 2020: a research report for the Cardio \& Vascular Coalition and the British Heart Foundation [Internet]. London: British Heart Foundation; 2008 [cited 2013 Sep 11]. Available from: http://www.bhf.org.uk/plugins/ PublicationsSearchResults/DownloadFile.aspx?docid=ad18e5a0-7da64c7c-8142-f68f27cde451

5. World Health Organization. Global health risks: mortality and burden of disease attributable to selected major risks [Internet]. Geneva: WHO 2009 [cited 2013 Sep 11]. Available from: http://www.who.int/healthinfo/ global_burden_disease/GlobalHealthRisks_report_Front.pdf.

6. Smith SC Jr, Benjamin EJ, Bonow RO, Braun LT, Creager MA, Franklin $\mathrm{BA}$, et al. AHA/ACCF secondary prevention and risk reduction therapy for patients with coronary and other atherosclerotic vascular disease: 2011 update: a guideline from the American Heart Association and American College of Cardiology Foundation endorsed by the World Heart Federation and the Preventive Cardiovascular Nurses Association. J Am Coll Cardiol. 2011 Nov 29;58(23):2432-46.

7. Sofi F, Fabbri A, Marcucci R, Gori AM, Balzi D, Barchielli A, et al. Lifestyle modifications after acute coronary syndromes in a subset of the AMI-Florence 2 Registry. Acta Cardiol. 2011 Dec;66(6):791-6.

8. Keys A, Blackburn H, Menotti A, Buzina R, Mohacek I, Karvonen MJ, et al. Coronary heart disease in seven countries. Circulation. 1970;41 Suppl 1:1-211.

9. Panagiotakos D. A Mediterranean diet supplemented with olive oil or nuts reduces the incidence of major cardiovascular events in high-risk patients. Evid Based Med. 2014 Feb;19(1):10. doi:10.1136/eb-2013-101391.

10. de Lorgeril M, Salen P, Martin JL, Monjaud I, Delaye J, Mamelle N Mediterranean diet, traditional risk factors, and the rate of cardiovascular complications after myocardial infarction: final report of the Lyon Diet Heart Study. Circulation. 1999 Feb 16;99(6):779-85

11. Panagiotakos DB, Arapi S, Pitsavos C, Antonoulas A, Mantas Y, Zombolos $\mathrm{S}$, et al. The relationship between adherence to the Mediterranean diet and the severity and short-term prognosis of acute coronary syndromes (ACS): The Greek Study of ACS (The GREECS). Nutrition. 2006 JulAug;22(7-8):722-30.

12. Trichopoulou A, Bamia C, Norat T, Overvad K, Schmidt EB, Tjønneland A, et al. Modified Mediterranean diet and survival after myocardial infarction: the EPIC-Elderly study. Eur J Epidemiol. 2007;22(12):871-81.

13. Strazzullo P, D'Elia L, Kandala NB, Cappuccio FP. Salt intake, stroke, and cardiovascular disease: meta-analysis of prospective studies. BMJ 2009 Nov 24;339:b4567. doi: 10.1136/bmj.b4567.

14. Kastorini CM, Milionis HJ, Kalantzi K, Trichia E, Nikolaou V, Vemmos $\mathrm{KN}$, et al. The mediating effect of the Mediterranean diet on the role of discretionary and hidden salt intake regarding non-fatal acute coronary syndrome or stroke events: case/case-control study. Atherosclerosis. 2012 Nov;225(1):187-93.

15. He K, Song Y, Daviglus ML, Liu K, Van Horn L, Dyer AR, et al. Accumulated evidence on fish consumption and coronary heart disease mortality: a meta-analysis of cohort studies. Circulation. 2004 Jun 8;109(22):2705-11.

16. Erkkilä AT, Lehto S, Pyörälä K, Uusitupa MI. n-3 Fatty acids and 5-y risks of death and cardiovascular disease events in patients with coronary artery disease. Am J Clin Nutr. 2003 Jul;78(1):65-71

17. Ramsden CE, Zamora D, Leelarthaepin B, Majchrzak-Hong SF, Faurot $\mathrm{KR}$, Suchindran CM, et al. Use of dietary linoleic acid for secondary prevention of coronary heart disease and death: evaluation of recovered data from the Sydney Diet Heart Study and updated meta-analysis. BMJ. 2013 Feb 4;346:e8707. doi: 10.1136/bmj.e8707.

18. Micha R, Wallace SK, Mozaffarian D. Red and processed meat consumption and risk of incident coronary heart disease, stroke, and diabetes mellitus: a systematic review and meta-analysis. Circulation. 2010 Jun $1 ; 121(21): 2271-83$
19. Perk J, De Backer G, Gohlke H, Graham I, Reiner Ž, Verschuren WMM, et al.; European Association for Cardiovascular Prevention \& Rehabilitation (EACPR); ESC Committee for Practice Guidelines (CPG). European Guidelines on cardiovascular disease prevention in clinical practice (version 2012). The Fifth Joint Task Force of the European Society of Cardiology and Other Societies on Cardiovascular Disease Prevention in Clinical Practice (constituted by representatives of nine societies and by invited experts). Eur Heart J. 2012 Jul;33(13):1635-701.

20. Gordon T, Kannel WB. Drinking habits and cardiovascular disease: the Framingham Study. Am Heart J. 1983 Apr;105(4):667-73.

21. Costanzo S, Di Castelnuovo A, Donati MB, Iacoviello L, de Gaetano G. Alcohol consumption and mortality in patients with cardiovascular disease: a meta-analysis. J Am Coll Cardiol. 2010 Mar 30;55(13):1339-47.

22. Rehm J, Sempos CT, Trevisan M. Average volume of alcohol consumption, patterns of drinking and risk of coronary heart disease - a review. J Cardiovasc Risk. 2003 Feb;10(1):15-20.

23. de Lorgeril M, Salen P, Martin JL, Boucher F, de Leiris J. Interactions of wine drinking with omega-3 fatty acids in patients with coronary heart disease: a fish-like effect of moderate wine drinking. Am Heart J. 2008 Jan;155(1):175-81

24. Collins MA, Neafsey EJ, Mukamal KJ, Gray MO, Parks DA, Das DK, et al. Alcohol in moderation, cardioprotection, and neuroprotection: epidemiological considerations and mechanistic studies. Alcohol Clin Exp Res. 2009 Feb;33(2):206-19.

25. Hines LM, Stampfer MJ, Ma J, Gaziano JM, Ridker PM, Hankinson SE, et al. Genetic variation in alcohol dehydrogenase and the beneficial effect of moderate alcohol consumption on myocardial infarction. N Engl J Med. 2001 Feb 22;344(8):549-55.

26. Mukamal KJ, Maclure M, Muller JE, Sherwood JB, Mittleman MA. Prior alcohol consumption and mortality following acute myocardial infarction. JAMA. 2001 Apr 18;285(15):1965-70.

27. Little HJ. Behavioral mechanisms underlying the link between smoking and drinking. Alcohol Res Health. 2000;24(4):215-24.

28. Lee SJ, Sudore RL, Williams BA, Lindquist K, Chen HL, Covinsky KE. Functional limitations, socioeconomic status, and all-cause mortality in moderate alcohol drinkers. J Am Geriatr Soc. 2009 Jun;57(6):955-62.

29. Pitsavos C, Kavouras SA, Panagiotakos DB, Arapi S, Anastasiou CA, Zombolos S, et al.; GREECS Study Investigators. Physical activity status and acute coronary syndromes survival The GREECS (Greek Study of Acute Coronary Syndromes) study. J Am Coll Cardiol. 2008 May 27;51(21):2034-9.

30. Logue J, Murray HM, Welsh P, Shepherd J, Packard C, Macfarlane P, et al. Obesity is associated with fatal coronary heart disease independently of traditional risk factors and deprivation. Heart. 2011 Apr;97(7):564-8.

31. Green P, Newman JD, Shaffer JA, Davidson KW, Maurer MS, Schwartz JE. Relation of patients living without a partner or spouse to being physically active after acute coronary syndromes (from the PULSE accelerometry substudy). Am J Cardiol. 2013 May 1;111(9):1264-9.

32. Molloy GJ, Hamer M, Randall G, Chida Y. Marital status and cardiac rehabilitation attendance: a meta-analysis. Eur J Cardiovasc Prev Rehabil. 2008 Oct;15(5):557-61.

33. Vanhees L, Rauch B, Piepoli M, van Buuren F, Takken T, Börjesson M, et al.; Writing Group, EACPR. Importance of characteristics and modalities of physical activity and exercise in the management of cardiovascular health in individuals with cardiovascular disease (Part III). Eur J Prev Cardiol. 2012 Dec;19(6):1333-56.

34. Kannel WB, Dawber TR, Kagan A, Revotskie N, Stokes J 3rd. Factors of risk in the development of coronary heart disease - six year follow-up experience. The Framingham Study. Ann Intern Med. 1961 Jul;55:33-50.

35. De Bacquer D, Dallongeville J, Kotseva K, Cooney MT, Pajak A, Deckers JW, et al. Residual risk of cardiovascular mortality in patients with coronary heart disease: The EUROASPIRE Risk Categories. Int J Cardiol. 2013 Sep 30;168(2):910-4

36. Newby DE, Wright RA, Labinjoh C, Ludlam CA, Fox KA, Boon NA, et al. Endothelial dysfunction, impaired endogenous fibrinolysis, and cigarette smoking: a mechanism for arterial thrombosis and myocardial infarction. Circulation. 1999 Mar 23;99(11):1411-5.

37. Pyrgakis VN. Smoking and cardiovascular disease. Hellenic J Cardiol. 2009 May-Jun;50(3):231-4.

38. Scholte op Reimer W, de Swart E, De Bacquer D, Pyörälä K, Keil U, Heidrich J, et al. Smoking behaviour in European patients with established coronary heart disease. Eur Heart J. 2006 Jan;27(1):35-41.

39. Berndt N, Bolman C, Mudde A, Verheugt F, de Vries H, Lechner L. Risk groups and predictors of short-term abstinence from smoking in patients with coronary heart disease. Heart Lung. 2012 Jul-Aug;41(4):332-43. 
40. De Backer G, Ambrosioni E, Borch-Johnsen K, Brotons C, Cifkova R, Dallongeville J, et al. European guidelines on cardiovascular disease prevention in clinical practice. Third Joint Task Force of European and other Societies on Cardiovascular Disease Prevention in Clinical Practice. Eur Heart J. 2003 Sep;24(17):1601-10.

41. World Health Organization, Commission on Social Determinants of Health. Closing the gap in a generation: health equity through action on the social determinants of health. Final Report of the Commission on Social Determinants of Health [Internet]. Geneva: WHO; 2008 [cited 2013 Sep 11]. Available from: http://whqlibdoc.who.int/publications/2008/9789241563703 eng.pdf.

42. World Health Organization. The financial crisis and global health: report of a high-level consultation, Geneva, Switzerland, 19 January 2009. Geneva: WHO; 2009.

43. Notara V, Koupidis SA, Vaga E, Grammatikopoulos IA. Economic crisis and challenges for the Greek healthcare system: the emergent role of nursing management. J Nurs Manag. 2010 Jul;18(5):501-4.

44. Koren A, Steinberg DM, Drory Y, Gerber Y; Israel Study Group on First Acute Myocardial Infarction. Socioeconomic environment and recurrent coronary events after initial myocardial infarction. Ann Epidemiol. 2012 Aug;22(8):541-6.

45. Pitsavos CE, Panagiotakos DB, Chrysohoou CA, Skoumas J, Stefanadis C, Toutouzas PK. Education and acute coronary syndromes: results from the CARDIO2000 epidemiological study. Bull World Health Organ. 2002;80(5):371-7.
46. Panagiotakos DB, Pitsavos C, Kogias Y, Mantas Y, Zombolos S, Antonoulas A, et al. Marital status, depressive episodes, and short-term prognosis of patients with acute coronary syndrome: Greek study of acute coronary syndrome (GREECS). Neuropsychiatr Dis Treat. 2008 Apr;4(2):425-32.

47. Lammintausta A, Airaksinen JK, Immonen-Räihä P, Torppa J, Kesäniemi AY, Ketonen M, et al.; FINAMI Study Group. Prognosis of acute coronary events is worse in patients living alone: the FINAMI myocardial infarction register. Eur J Prev Cardiol. 2013 Jan 30;21(8):989-996.

48. Berkman LF, Blumenthal J, Burg M, Carney RM, Catellier D, Cowan MJ, et al.; Enhancing Recovery in Coronary Heart Disease Patients Investigators (ENRICHD). Effects of treating depression and low perceived social support on clinical events after myocardial infarction: the Enhancing Recovery in Coronary Heart Disease Patients (ENRICHD) Randomized Trial. JAMA. 2003 Jun 18;289(23):3106-16.

49. Aboa-Eboulé C, Brisson C, Maunsell E, Mâsse B, Bourbonnais R, Vézina $\mathrm{M}$, et al. Job strain and risk of acute recurrent coronary heart disease events. JAMA. 2007 Oct 10;298(14):1652-60.

50. European Heart Health Charter. Part II: Signatories recognise that [Internet]. Sophia Antipolis: European Society of Cardiology; 2007 [cited 2014 April 15]. Available from: http://www.heartcharter.org/read-charter/ part-2.aspx.

Received September 30, 2013 Accepted in revised form April 3, 2014 